\title{
In vitro studies on inhibition capability of fungal-sourced bassiatin versus tamoxifen against ERa, EGFR and VEGFR on breast cancer cells
}

\author{
Erkay Özgör ${ }^{1 *}$ Nevin Keskin ${ }^{2}$ \\ ${ }^{1}$ Cyprus International University, Department of Molecular Biology and Genetics, 99258, Lefkoşa, via Mersin 10, TURKEY \\ ${ }^{2}$ Hacettepe University, Department of Biology, Ankara, TURKEY
}

\begin{abstract}
Bassiatin which is produced by some fungi, is morpholine-based depsipeptide. Recent studies show that bassiatin inhibits MCF-7 breast cancer cell proliferation with its anti-oestrogenic effect. In this study, bassiatin's inhibition versus Tamoxifen was examined by comparing the effects on epidermal growth factor receptor and vascular endothelial growth factor receptor in addition to oestrogen receptor on breast cells. For this purpose, 15 concentrations of bassiatin, tamoxifen and combination of both were treated in terms of cytotoxicity on MCF-7, MDA-MB-231, SK-BR-3 and SVCT cell lines. For cell cycle analyses, MCF-7 and SVCT cell lines were incubated with $37.5 \mu$ M bassiatin, tamoxifen and combined substance for $24 \mathrm{~h}$ and $48 \mathrm{~h}$. After treatment, cell distribution in each phase of the cell cycle was measured with flow cytometer. Furthermore, each interaction related to receptors were investigated with immunoassay ELISA kits. As a result, bassiatin-induced MCF-7 cell cycle arrest was shown in G0/G1 and G2/M phases at the presence of bassiatin. It was also found that bassiatin is more effective at all examined receptors on breast cancer cells than tamoxifen. These results show that bassiatin can be used effectively in breast cancer treatment as a new anticancer agent because of its multiple inhibition effects.
\end{abstract}

Keywords: cell cycle; MCF-7; SVCT

Article history: Received 22 April 2020, Revised 24 September 2020, Accepted 9 November 2020, Available online 20 March 2021

\section{Introduction}

Bassiatin ((3R,6R)-3-benzyl-4-methyl-6-propan-2-ylmorpholine2,5-dione) (Fig. 1) is a newly discovered morpholine-based depsipeptide which is produced by some soil-sourced fungi, including entomopathogenic and phytopathogenic species (Keller et al., 2005). Bassiatin is reported to be a platelet aggregation inhibitor (Kagamizono et al., 1995), and its stereoisomer, lateritin (3-benzyl-4-methyl6-propan-2-ylmorpholine-2,5-dione), had an inhibitory effect on the growth of some human cancer cell lines, Gram-positive bacteria and Candida albicans (Pettit et al., 2010). Bassiatin is also found to be an antibacterial agent on methicillin-resistant Staphylococcus aureus (Keskin et al., 2016). Recent studies show that bassiatin inhibits cell proliferation and cell cycle progression on MCF-7 breast cancer cell line by repressing cyclin D1 expression and inducing apoptosis via activation of the ERK-MAPK pathway (Meng et al., 2011, Meng et al., 2012). Furthermore, it is also reported that bassiatin has an antiestrogenic effect on MCF-7 Estrogen Receptor $\alpha(\mathrm{ER} \alpha)$ positive breast cancer cell line. However, the results of these studies didn't show the comparison between bassiatin and today's antiestrogenic agents in terms of cytotoxic activity. In addition, it has not been totally under-

\footnotetext{
* Corresponding author.

Cyprus International University, Department of Molecular Biology and Genetics, Faculty of Arts and Sciences, 99258, Lefkoşa, via Mersin 10, TURKEY, e-mail: eozgor@ciu.edu.tr, Phone: +903926711111/2052, Fax: +903926711132
}

stood that bassiatin has only hormone-based inhibition.

Cancer which is regarded as the disease of our age varies because of its different foci depending on environmental and genetic factors. When we look at the world average, it is known that the most frequent and high-mortality cancer in women is breast cancer (Jemal et al., 2011). Although many important advances have been made for early detection and effective treatment of breast cancer, breast cancer-induced mortality rates have increased over the past 30 y (Al-Hajj et al., 2003).

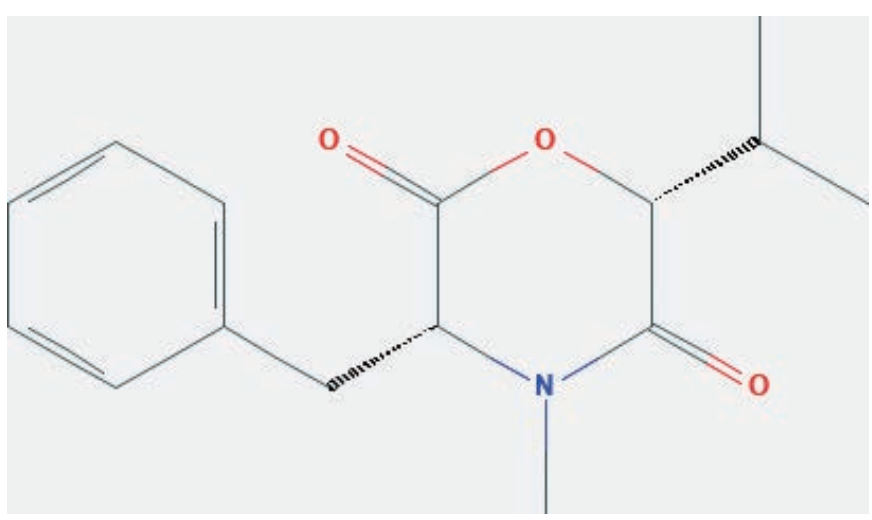

Fig. 1. Molecular structure of bassiatin 
Even if drugs used in hormonotherapy or chemotherapy are treated individually or in combination to the patient for the effective treatment of breast cancer, the disease process can result in death (Muss et al., 1991). Many drugs have been used in the active treatment of breast cancer as in many diseases in recent years. These drugs include doxorubicin, docetaxol, anastrozole, and tamoxifen (Andre et al., 2004). The treatment of breast cancer is changing and developing together with these drugs and the newly discovered specific cytotoxic agents and so that more positive results are obtained on breast cancer. In today's conditions, successful results are generally obtained with the protocols used in the treatment of breast cancer, but medicines used in treatment sometimes cause metabolic disorders and side effects on normal tissues and organs. In addition, after intensive use of drugs, the development of resistance to drugs can also be observed and the treatment may fail. The high cost and market value of today's drugs have led to the discovery of alternative anti-tumour agents. Since fungi produce a wide range of natural products that have antimicrobial and anti-tumour effects, many fungal products are produced industrially (Huang et al., 2008).

In ER $\alpha$-positive breast cancer cells MCF-7, ER $\alpha$ plays a dominant role in cell proliferation (Ruff et al., 2000, Ikeda \& Inoue, 2004). But it is known that there are also different focuses to affect the cell proliferation except for oestrogen. The effects of Epithelial Growth Factor and Vascular Endothelial Growth Factor on breast cancer formation have been known since approximately $15 \mathrm{y}$. Epithelial Growth factor shows its effect by binding Epithelial Growth Factor Receptor (EGFR) which is found most breast cancer cells and cancerous cells grow and multiply with these interactions (Olayioye, 2001, Walker \& Dearing, 1999). Vascular Endothelial Growth Factor is produced by breast carcinoma cells to stimulate angiogenesis and contribute the spread of cancer by binding Vascular Endothelial Growth Factor Receptor (VEGFR) (Guo et al., 2003). When EGFR and VEGFR express in these tumour types, tumours cannot respond to endocrine treatments and the lifespan of the patient decreases. EGFR and VEGFR's are found breast cancer cell lines both ER-negative (MDA-MB-231, SK-BR-3 and Hs578T) and ER-positive (MCF7, T47D and ZR-75-1) (Olayioye, 2001, Guo et al., 2003). Therefore, it is expected that the agent to be used effectively in breast cancer treatment should have both antiestrogenic effect and other receptor-based (EGFR and VEGFR) inhibition capability.

The aim of this study is to investigate the inhibition capability of bassiatin against EGFR and VEGFR on MCF-7 (ER+, PR+, HER2/ Neu-) breast cancer cell lines besides its antiestrogenic effect with comparing MDA-MB-231 (ER-, PR-, HER2/Neu-) and SK-BR-3 (ER-, PR-, HER2/Neu++) breast cancer cell lines and SVCT non-tumorigenic normal breast epithelium cell line. Furthermore, the efficacy of bassiatin on breast cancer cell lines have been investigated compared to standard SERM tamoxifen active substance which is currently used in hormonotherapy, one of the breast cancer treatment. It has been also evaluated whether the combined use of bassiatin and tamoxifen increases inhibitor effectiveness.

\section{Materials and methods}

\subsection{Bassiatin production.}

Beauveria bassiana (KVL-03129 strain given by Nicolai V. Meyling from The Royal Veterinary and Agricultural University, Copenhagen, submitted to ARSEF (Catalog of Species); GenBank Accession Number: ASM168263v1) was selected to obtain a high amount of bassiatin. Bassiatin was produced in a $250 \mathrm{~mL}$ shaking liquid medium containing $0.3 \%$ yeast extract, $0.3 \%$ malt extract, $0.5 \%$ pep- tone, $2 \%$ glucose, $0.05 \% \mathrm{KH}_{2} \mathrm{PO}_{4}$ and $0.05 \% \mathrm{NH}_{4} \mathrm{Cl}$ at $\mathrm{pH} 6.5$ under $28{ }^{\circ} \mathrm{C}$ for $9 \mathrm{~d}$ using $\mathrm{B}$. bassiana (Meng et al., 2011). The culture broth was filtered with the help of Buhner funnel using sterile Whatman No.1 filter paper and the same amount of ethyl acetate (EtOAc) was treated with culture broth. This mixture was extracted by using the separated funnel. EtOAc extract was evaporated with Rotary evaporator (Heidolph, Laborota 4000, Schwabach) under pressure. The residue obtained from the evaporation stage contains bassiatin and other organic chemicals. The residue was dissolved with the minimal amount of chloroform $\left(\mathrm{CHCl}_{3}\right)$ and prepared for 2-staged chromatography. In the first stage, the dissolved residue was added to the Sephadex-filled (Cytiva, G-25, Superfine, Buccinasco) column and substances within the colon were eluted with 50:50 rated $\mathrm{CHCl}_{3}: \mathrm{MeOH}$ (Chloroform-Methanol) mixture. The separation of bassiatin from other compounds was provided with the second chromatography process by using silica gel-filled $\left(60 \mathrm{~A}^{\circ}\right.$, 0.015-0.040 mm, Merck) column and bassiatin was eluted with $\mathrm{CHCl}_{3}: \mathrm{MeOH}(65: 35)$ mixture. For the purification of pure and high-yielded bassiatin, Preparative HPLC (Agilent Technologies, 1260 İnfinity, California) was done by using 100-5-C18 (4.0 × 100 $\mathrm{mm}$ ) specific column (Kromasil ${ }^{\circledR}$, Munich). Bassiatin-contained elution was prepared with $\mathrm{MeOH}$ :Water (80:20) mixture and it is processed in 98 bar pressure at $4 \mathrm{~mL} / \mathrm{min}$ within the HPLC device. The peak range of bassiatin was seen at $2.681 \mathrm{~min}$ and found to be higher than $800 \mathrm{mAU}$. End of the process, pure bassiatin was collected at the collection part of the HPLC device (Meng et al., 2011). The purity of obtained bassiatin was determined by evaluating $\mathrm{H}$ NMR and C NMR spectrum data with $400 \mathrm{MHz}$ AV model NMR spectrometer (Table 1).

Table 1. ${ }^{1} \mathrm{H}$ and ${ }^{13} \mathrm{C}$ NMR chemical shifts of bassiatin (3R,6R)

\begin{tabular}{lrl}
\hline & ${ }^{\delta} \mathbf{C}(\mathbf{p p m})$ & \multicolumn{1}{c}{${ }^{\delta} \mathbf{H}(\mathbf{p p m})$} \\
\hline $\mathbf{C}-\mathbf{2}$ & 171.55 & \\
$\mathbf{C}-\mathbf{3}$ & 61.47 & $4.57(1 \mathrm{H}, \mathrm{t}, J=6.571 \mathrm{~Hz})$ \\
$\mathbf{C}-\mathbf{5}$ & 170.94 & \\
$\mathbf{C}-\mathbf{6}$ & 79.4 & $5.59(1 \mathrm{H}, \mathrm{d}, J=3.588 \mathrm{~Hz})$ \\
$\mathbf{C - 7}$ & 30.66 & $2.10(1 \mathrm{H}, \mathrm{septd}, J=6.942 \mathrm{~Hz}, 3.588 \mathrm{~Hz})$ \\
$\mathbf{C - 8 , 9}$ & 18.46 & $0.89(3 \mathrm{H}+3 \mathrm{H}, \mathrm{d}, J=6.942)$ \\
$\mathbf{C - 1 0}$ & 34.99 & $2.99(2 \mathrm{H}, \mathrm{d}, J=6.571 \mathrm{~Hz})$ \\
$\mathbf{C - 1 1}$ & 136.9 & \\
$\mathbf{C - 1 2 , 1 6}$ & 129.12 & $7.25(2 \mathrm{H}, \mathrm{dddd}, J=7.762 \mathrm{~Hz}, 1.194 \mathrm{~Hz}, 0.536 \mathrm{~Hz})$ \\
$\mathbf{C - 1 4}$ & 128.92 & $7.24(1 \mathrm{H}, \mathrm{tt}, J=7.724 \mathrm{~Hz}, 1.503 \mathrm{~Hz})$ \\
$\mathbf{C - 1 3 , 1 5}$ & 128.71 & $7.25(2 \mathrm{H}, \mathrm{tdd}, J=7.724 \mathrm{~Hz}, 1.843 \mathrm{~Hz}, 0.536 \mathrm{~Hz})$ \\
$\mathbf{N}-\mathbf{C H 3}$ & 32.81 & $3.08(3 \mathrm{H}, \mathrm{s})$ \\
\hline
\end{tabular}

\subsection{Cell lines and cell culture}

For this study, MCF-7 (ER+, PR+, HER2/Neu-), MDA-MB-231 (triple-negative: ER-, PR-, HER2/Neu-) and SK-BR-3 (ER-, PR-, HER2/Neu++) as breast cancer cell lines and SVCT as a non-tumorigenic normal breast epithelial cell line were selected. Cell lines which are stocked in the freezer were firstly cultivated for cytotoxicity tests. The culture medium used for the cultivation of MCF-7 and MDA-MB-231 cell lines (ATCC) contains DMEM/F12 (Dulbecco's modified Eagle's medium $)+2 \mathrm{mM}$ Glutamine $+10 \%$ Foetal Bovine Serum (FBS) + penicillin/streptomycin while the culture medium of SK-BR-3 cell line contains McCoy's 5A with $+2 \mathrm{mM}$ Glutamine $+10 \%$ Foetal Bovine Serum (FBS) + penicillin/streptomycin. All breast cancer cells were incubated at the standard conditions $\left(5 \% \mathrm{CO}_{2}, 37^{\circ} \mathrm{C}\right)$.

SVCT cell line was purchased from The European Collection of Authenticated Cell Cultures (ECACC 94122105). SVCT has been established from human breast epithelial cells being transfected with SV40. GMO status is showed as Genetically Modified Organ- 
ism Class 1. SVCT have been found positive for the expression of keratin 7, 8 and 18 but negative for keratin 19. Epithelial cells, dome formation when confluent. SVCT cell line needs specific compounds in its culture medium; DMEM + $2 \mathrm{mM}$ Glutamine +5 $\mu \mathrm{g} / \mathrm{mL}$ Hydrocortisone $+10 \mu \mathrm{g} / \mathrm{mL}$ Insulin + penicillin/streptomycin $+10 \%$ FBS.

\subsection{Cytotoxicity studies}

Cytotoxicity of bassiatin was determined by using MTT assay which evaluates metabolic activities of cells with a colorimetric method. In this study, toxicities of obtained bassiatin and tamoxifen active substance on MCF-7, MDA-MB-231, SK-BR-3 and SVCT cell lines were investigated and toxic doses of these substances were determined. Because of the widespread use of combined drug therapy in cancer treatments, the cytotoxic effect of the combined substance prepared in 1:1 ratio with bassiatin and tamoxifen has been investigated on all cell lines. Within these scopes, produced cell lines were collected with trypsinization from flasks and then centrifuged. Pellets were used to prepare cell suspensions and cell counting was done to determine the number of cells in each suspension. For cell counting; $900 \mu \mathrm{L}$ cell suspension was transferred to the eppendorf tube which has $100 \mu \mathrm{L}$ Trypan blue $(0.5 \% \mathrm{w} / \mathrm{v}$, Biochrom, Cambridge) inside. Vital cell counting was performed with this suspension using an improved Neubauer slide under the light microscope (Leica, DM750, Wetzlar). Cytotoxicity study was prepared by inoculating $1 \times 10^{5}$ cell/well in 96 -well plates. After $24 \mathrm{~h}$ in the standard incubation conditions, medium cultures in wells were discarded and substances which will be tested in terms of cytotoxicity were added to the wells. It was used different 96-well plates for each incubation period (24, 48 and $74 \mathrm{~h}$ ) and each substance which will be tested in this study. 15 different concentrations $(0.25,0.5,1.25,2,2.5,3,3.75,5,6.25,7.5,12.5,18.75,25,37.5$ and $75 \mu \mathrm{M}$ ) were prepared for each substance and these concentrations were used as a 6 repeated in cytotoxicity studies. Six wells were evaluated as a control group in each 96-well plate.

For MTT analyses, MTT solvent was prepared with 1:10 rated MTT:Serum-free medium. After incubation with substances, medium cultures in wells were discarded, $200 \mu \mathrm{L}$ MTT solvent $(5 \mathrm{mg} /$ $\mathrm{mL}$ ) was added in each well and plates were incubated in dark 5\% $\mathrm{CO}_{2}$ and $37^{\circ} \mathrm{C}$ conditions for $4 \mathrm{~h}$. MTT solvent was discarded from each well after incubation. $100 \mu \mathrm{L}$ isopropyl alcohol contains 0.05 $\mathrm{N} \mathrm{HCl}$ was added in each well and reading was performed with ELISA reader (Biotech, $\mu$ Quant, Vermont) which is adjusted to 570 $\mathrm{nm}$. Obtained data were used for statistical studies.

\subsection{Cell imaging}

Based on cytotoxicity studies, wells were prepared with the same concentrations of substances for imaging of substance-based inhibition and apoptosis of cells with florescent dying and imaging was made daily. 50:50 rated Acridine Orange/Propidium Iodide (AO/PI) florescent dye mixture was used for imaging. For this purpose, medium cultures in wells were collected and each well was washed with $10 \times$ Phosphate-buffered saline (PBS). $100 \mu \mathrm{L} \mathrm{AO/PI}$ was treated to cells in washed-wells for $20 \mathrm{~s}$. After collecting dye, wells were washed with PBS in $10 \mathrm{~s}$ and imaged with florescent microscope (Olympus, Waltham).

\subsection{Detection of apoptotic cells with propidium iodide (PI) and cell cycle analyses}

The apoptosis situation of MCF-7 and SVCT cell lines and cell cycle analyses were conducted at Cancer Institute of Hacettepe University. Apoptosis was detected using PI florescent dye. After 24 and $48 \mathrm{~h}$ incubation of MCF-7 and SVCT cells with $37.5 \mu \mathrm{M}$ bassiatin, tamoxifen and combined substance, $1 \mathrm{~mL}$ PBS and $2 \mathrm{~mL} 99 \%$ purely ethanol was added drop by drop on $1.5 \times 10^{6} / \mathrm{mL}$ cells respectively and cells were fixed. Following an incubation at $+4{ }^{\circ} \mathrm{C}$ for a night, cells were washed twice with PBS and $70 \mu \mathrm{L}$ RNase and 100 $\mu \mathrm{L}$ PI were added on cells. After incubation in dark at room temperature for $30 \mathrm{~min}$, late apoptosis and cell cycle analyses were done by counting 10,000 cells with flow cytometry (Beckman Coulter EPICS XLMCL, California). The SubG1 peak which shows DNA fragmentation was evaluated for late apoptosis. It is thought that cell cycle evaluation has also contributed to the study. G0/G1, Synthesis and G2/M rates were calculated from two-variable histograms with Multicycle software program (Phoenix system, San Diego) for cell cycle analyses (Deeb et al., 2007, Meng et al., 2011).

\subsection{Quantitative measurement of ERa, EGFR and VEGFR}

Interactions of bassiatin with receptors to which bind oestrogen alpha $(\alpha)$, epithelial growth factor (EGF) and vascular endothelial growth factor (VEGF) that influence the growth and development of breast cancer cells were investigated in the MCF-7 and SVCT cell line and the amounts of these receptors has been identified comparatively in cells. Cellular extracts were obtained for ER $\alpha$, EGFR and VEGFR analyses using commercial quantitative immunoassay kits.

In the quantitative measurement of $\mathrm{ER} \alpha$, the study was carried out in accordance with the protocol of the purchased ELISA kit (Abcam, ab128499, Cambridge). Nuclear extracts of cells were used at this stage. Dilution buffer containing $50 \mu \mathrm{g}$ nuclear extracts was added to the microplates supplied in the assay kit and sample wells were prepared for each nuclear extract. The MCF-7 nuclear extract in the manufacturer's kit was added to the control wells as a positive control. After $1 \mathrm{~h}$ of incubation at room temperature on a shaking platform, each well was washed 3 times with $1 \times$ wash buffer and primary detection antibodies were added to them $(50 \mu \mathrm{L}$ $\mathrm{ER} \alpha$ antibody). After $1 \mathrm{~h}$ of incubation on the shaking platform again, each well was washed 3 times with $1 \times$ wash buffer and treated with $50 \mu \mathrm{L}$ of HRP-conjugated secondary antibodies. The previous procedure was repeated and the colorimetric reaction with 100 $\mu \mathrm{L}$ of the developing solution was performed. The procedure was terminated with $100 \mu \mathrm{L}$ of stop solution. At this stage, the presence of acid is determined by the blue colour turning yellow. Measurements were made at $450 \mathrm{~nm}$ using an ELISA reader to read the absorbance. The results obtained by the manufacturer firm in the validation studies using this kit were evaluated as a reference.

Commercial ELISA kits have also been used to quantitatively determine EGFR and VEGFR (Abcam, ab192148 ab193764, Cambridge). The preparation of cell extracts and ELISA test protocol for both are the same. In preparing the cell extract for EGFR and VEG$\mathrm{FR}$, the direct lysis was preferred from the adherent cells. $50 \mu \mathrm{L}$ of each cell extract was added in the determined wells of the microplate supplied in the assay kit. $50 \mu \mathrm{L}$ of antibody cocktail was added to each well. Incubation was done for $1 \mathrm{~h}$ at room temperature on shaking platform and each well was washed with wash buffer. Subsequently, $100 \mu \mathrm{L}$ of TMB substrate was added to each well and incubated in a dark at $400 \mathrm{rpm}$ for $10 \mathrm{~min}$ on shaking platform. The experiment was terminated with $100 \mu \mathrm{L}$ of stop solution added to each buffer and OD values at $450 \mathrm{~nm}$ were obtained.

\subsection{Statistical analysis}

Evaluation of the effects of bassiatin, tamoxifen and combined 
substances on MCF-7 and SVCT cell lines was carried out by statistical studies. In addition, statistical studies have been carried out to compare MDA-MB-231 and SK-BR-3 cell lines with MCF-7 and SVCT cell lines. Kolmogorov-Smirnov test was performed to determine whether the data obtained from the studies had a normal distribution and it was determined that all the data did not show a normal distribution $(\mathrm{P}<0.05)$. Therefore, for both comparisons between cell lines and comparing time and matter concentrations; the Kruskal-Wallis test was used for multiple comparisons while the Mann-Whitney U test was used for binary comparisons.

\section{Results}

In this study to assess the toxicity of bassiatin in MCF-7, MDAMB-231, SK-BR-3 and SVCT cell lines; 15 different concentrations of bassiatin, tamoxifen and combined substance were applied on cell lines and MTT analyses were performed after 24,48 and $72 \mathrm{~h}$ of incubation. The substance-dependent inhibition in cells was visualized by fluorescence staining using a mixture of AO/PI fluorescent dyes. After $24 \mathrm{~h}$ of application, the effect between substances at a concentration of $75 \mu \mathrm{M}$ is visible (Fig. 2).

Comparisons of inhibition with most effective concentrations $(75,37.5$ and $25 \mu \mathrm{M})$ of different substances after $24 \mathrm{~h}$ incubation were also evaluated on MCF-7, MDA-MB-231, SK-BR-3 and SVCT

MCF-7
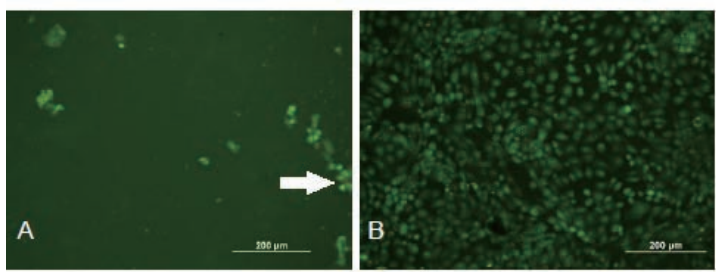

BASSIATIN
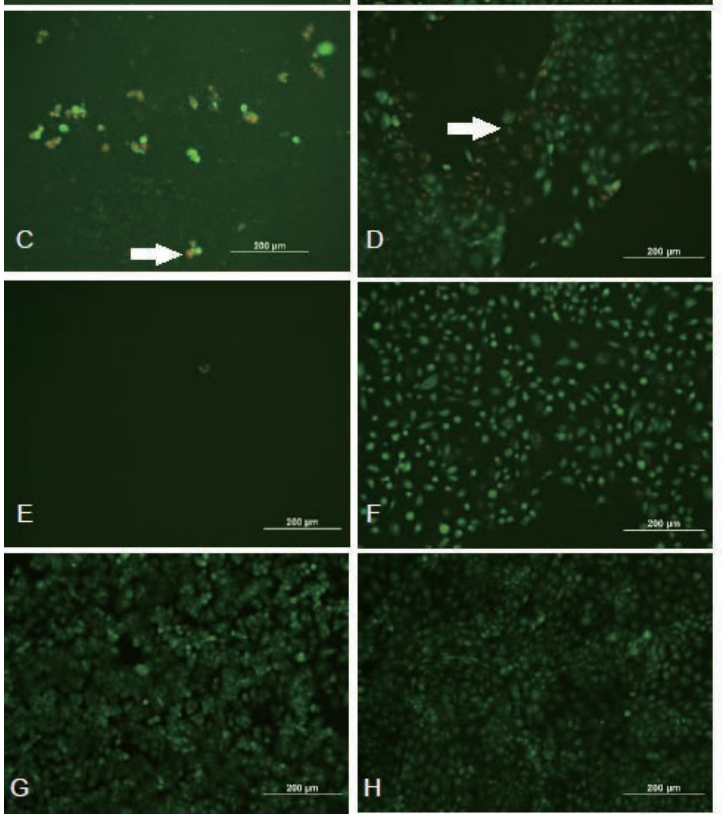

Fig. 2. Microscopic images of dyed cell lines after $24 \mathrm{~h}$ treatment with 50:50 rated Acridine Orange/Propidium Iodide (AO/PI) florescent dye mixture obtained from cytotoxicity studies. Inhibition of MCF-7 cell line with $75 \mu \mathrm{M}$ bassiatin (A), tamoxifen (C) and combined substance (E) and SVCT cell line with $75 \mu \mathrm{M}$ bassiatin (B), tamoxifen (D) and combined substance (F) were shown individually. Untreated MCF-7 (G) and SVCT (H) cells are also shown. Images which are contained cells treated with a high concentration of substances have apoptotic cells with red colour. Arrows show apoptotic cells giving a red fluorescent. All Figure scales are $200 \mu \mathrm{m}$. cell lines using bar graphs (Fig. 3). A comparison of the inhibition of $37.5 \mu \mathrm{M}$ bassiatin, tamoxifen and combined substance between the MCF-7 breast cancer cell line and the SVCT normal breast epithelial cell line was also shown by hourly with box-plot graphs (Fig. 4).

All concentrations of bassiatin, tamoxifen and combined substance on both MCF-7 and SCVT cells were compared with each other using the Kruskal-Wallis test after 24,48 and $72 \mathrm{~h}$ of incubation. A significant difference was found in all comparisons for MCF-7 ( $\mathrm{P}<0.05)$. In the comparison for SVCT, a significant difference was found between concentrations of tamoxifen and combined substance in the 24,48 and $72 \mathrm{~h}$ incubations $(\mathrm{P}<0.05)$ while there was no difference between the concentrations of bassiatin ( $P$ $>0.05$ ).

Four cell lines (MCF-7, MDA-MD-231, SK-BR-3 and SVCT) were compared in the direction of the data obtained as a result of cytotoxicity studies with bassiatin, tamoxifen and combined substance on cell lines (Mann-Whitney U, P $<0.05$ ). This comparison was performed separately for each concentration and incubation
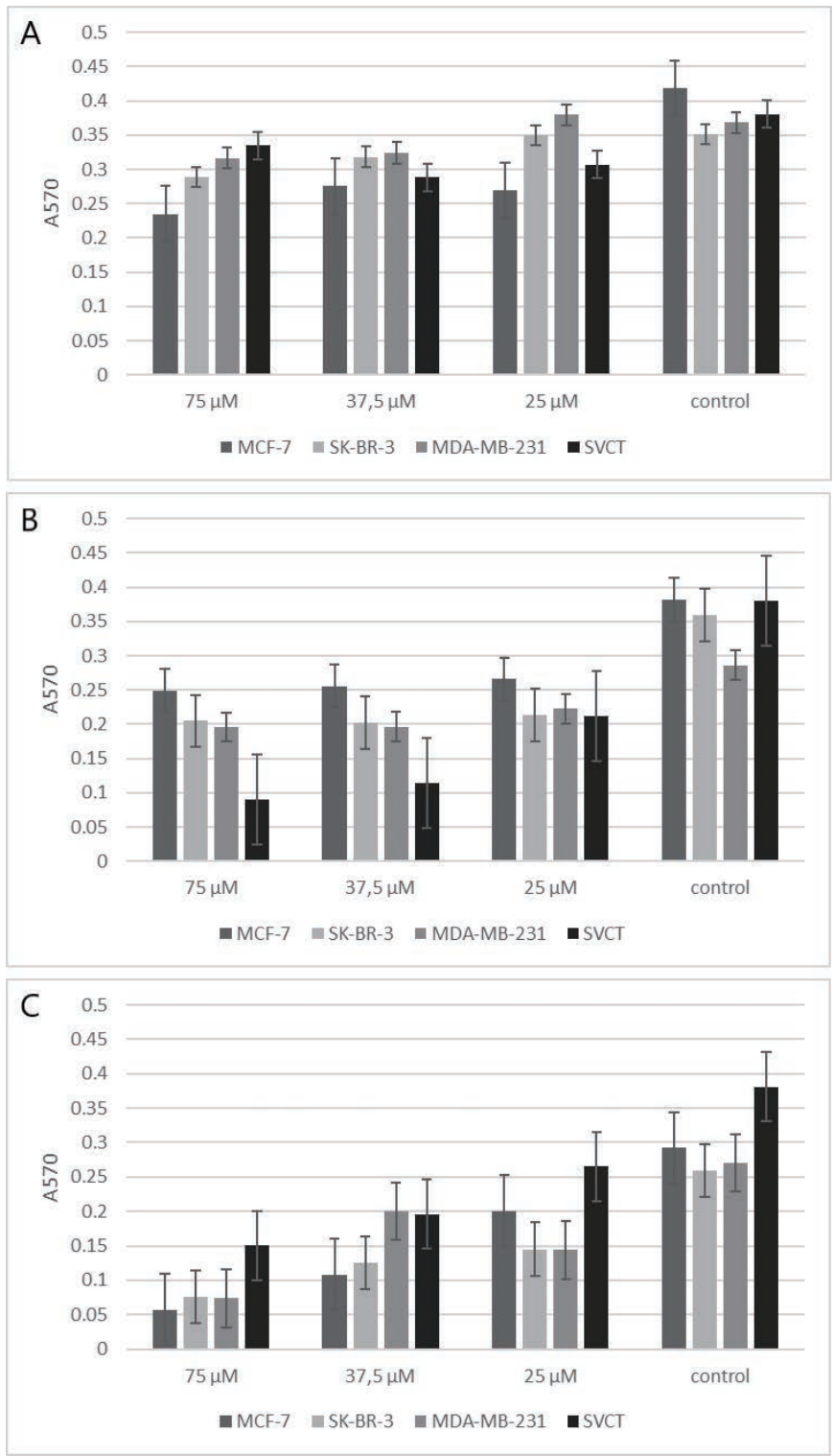

Fig. 3. Effects of $75,37.5$ and $25 \mu \mathrm{M}$ concentrations of bassiatin (A), tamoxifen (B) and combined substance (C) on MCF-7, MDA-MB-231, SK-BR-3 and SVCT cell lines after $24 \mathrm{~h}$ treatment. Data were obtained at the result of MTT analyses with $570 \mathrm{~nm}$ absorbance value of reading. 
period. In the results from the cytotoxicity studies performed with the cell lines, the concentration of the bassiatin providing a significant difference and the required dose for the treating patients was determined to be $37.5 \mu \mathrm{M}(0.75 \mathrm{mg} / \mathrm{mL})$ with EC50.

Among breast cancer cell lines, MCF-7 was selected to determine receptor-based inhibition of bassiatin at the cell cycle analyses and ELISA studies. MCF-7 and SVCT cell lines were incubated with $37.5 \mu \mathrm{M}$ bassiatin, tamoxifen and combined substance for 24 and $48 \mathrm{~h}$, and cell cycle analyses were performed using a flow cytometry. $24 \mathrm{~h}$ incubation period was shown by the bar graph. Bivariate histograms were obtained by evaluating cell cycle distribution in terms of G0/G1, Synthesis and G2/M ratios (Fig. 5).

The data obtained by investigating the effects of bassiatin on ER, EGFR and VEGFR with commercial ELISA kits were evaluated by

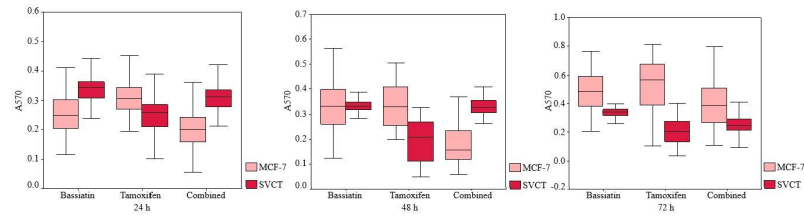

Fig. 4. Comparison of the inhibition of $37.5 \mu \mathrm{M}$ bassiatin, tamoxifen and combined substance hourly between MCF-7 and SVCT with box-plot graphs. The y-axis shows absorbance value obtained reading studies with $570 \mathrm{~nm}$.

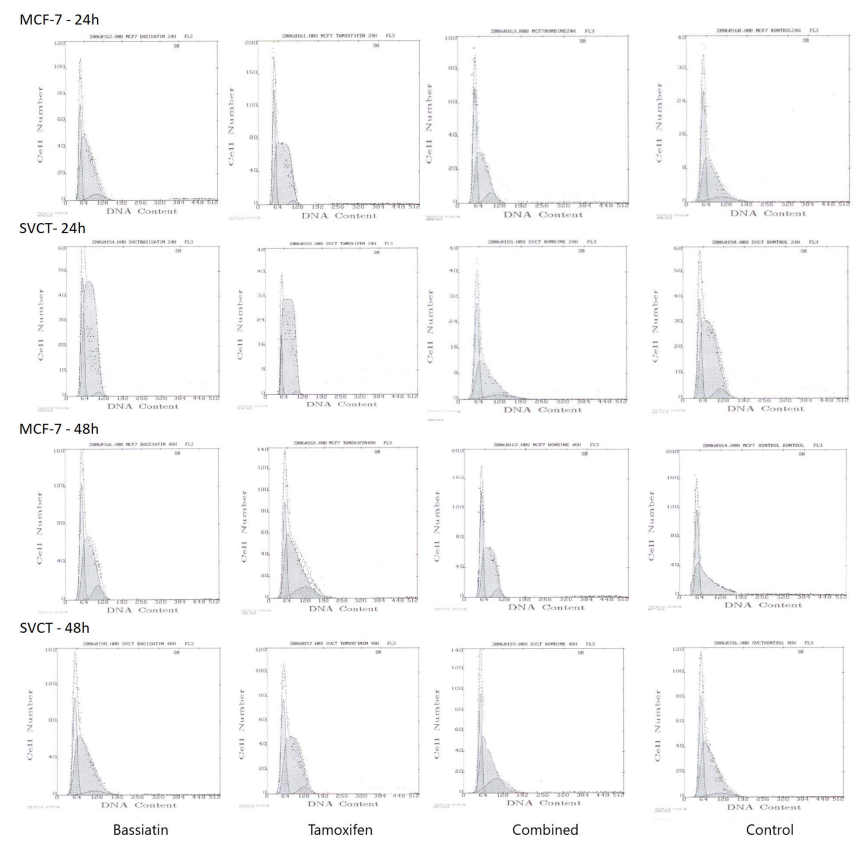

Fig. 5. Bivariate histograms of MCF-7 and SVCT Cell lines treated with $37.5 \mu \mathrm{M}$ bassiatin, tamoxifen and combined substance for 24 and $48 \mathrm{~h}$. The $\mathrm{x}$-axis shows the DNA content of each cell line while the $y$-axis indicates the number of cells during the flow cytometry. the generated graphs. For ER $\alpha$ detection, optical density values at $450 \mathrm{~nm}$ were used based on the amount of extract in each well and bar graphs were obtained. For EGFR and VEGFR detection, graphs were obtained based on the inhibition of receptors using optical densities at $450 \mathrm{~nm}$ (Fig. 6). The quantitative measurement of the amounts of the ER, EFGR and VEGFR in the samples were done by using standard curves which are obtained from OD values of the
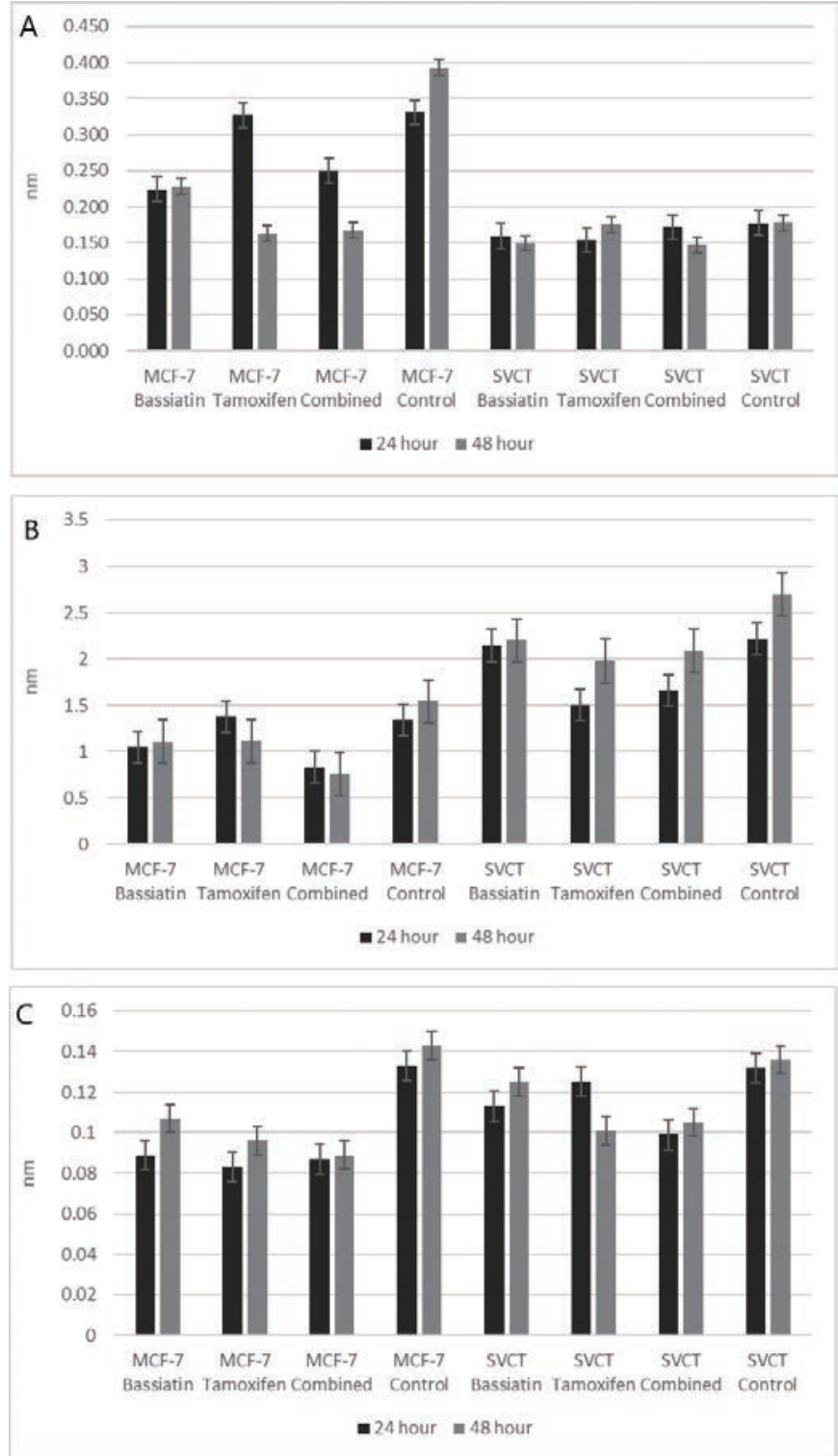

Fig. 6. Receptor blocking properties of $37.5 \mu \mathrm{M}$ bassiatin, tamoxifen and combined substance during 24 and $48 \mathrm{~h}$ incubation periods on ER (A), EGFR (B) and VEGFR (C) using optical densities at $450 \mathrm{~nm}$.

Table 2. The amounts of the ER, EGFR and VEGFR in the time-dependent bassiatin, tamoxifen and combine substance-treated MCF-7 and SVCT cells

\begin{tabular}{lrrrrrr}
\hline & \multicolumn{2}{c}{ ER $(\mathbf{p g} / \mathbf{m L})$} & \multicolumn{2}{c}{ EGFR $(\mathbf{p g} / \mathbf{m L})$} & \multicolumn{2}{c}{ VEGFR $(\mathbf{p g} / \mathbf{m L})$} \\
\cline { 2 - 7 } & $\mathbf{2 4} \mathbf{h}$ & $\mathbf{4 8 ~ h}$ & $\mathbf{2 4} \mathbf{h}$ & $\mathbf{4 8} \mathbf{~ h}$ & $\mathbf{2 4} \mathbf{h}$ & $\mathbf{4 8} \mathbf{~}$ \\
\hline MCF-7 bassiatin & 602 & 607 & 783 & 811 & 487 & 576 \\
MCF-7 tamoxifen & 889 & 455 & 1,100 & 813 & 469 & 526 \\
MCF-7 combined & 643 & 459 & 718 & 687 & 484 & 488 \\
MCF-7 control & 1,012 & 1,123 & 1,054 & 1,190 & 698 & 709 \\
SVCT bassiatin & 449 & 439 & 1,953 & 1,959 & 594 & 673 \\
SVCT tamoxifen & 445 & 503 & 1,150 & 1,876 & 673 & 533 \\
SVCT combined & 501 & 437 & 1,326 & 1,945 & 528 & 571 \\
SVCT control & 504 & 505 & 1,998 & 2,156 & 697 & 702 \\
\hline
\end{tabular}


standard of each receptor (Table 2).

\section{Discussion}

In this study, bassiatin, a newly discovered fungal product, was evaluated in terms of possible anti-tumour activity on breast cancer cell lines. Microscopic images obtained from cytotoxicity studies which are performed on breast cancer cell lines (MCF-7, MDAMB-231 and SK-BR-3) and normal breast epithelial cell line (SVCT) show that bassiatin and tamoxifen are effective on the MCF-7 breast cancer cell line at high concentrations in both individually and in combination. The substances were tested up to $75 \mu \mathrm{M}$ as the highest concentration starting from $0.25 \mu \mathrm{M}$ and it was shown that all substances (bassiatin, tamoxifen and combined substance) have a toxic effect on MCF-7 up to a certain density compared to control (Fig. 2). This is a normal result for tamoxifen, which is currently used as an inhibitor of the oestrogen receptor in breast cancer treatment. Tamoxifen and bassiatin were compared for the first time with this study. According to this; it has been shown that both substances have a cytotoxic effect in close proportions when used individually. However, the combined substance was statistically found to have a higher toxic effect on the MCF-7 cell line compared with the individual use of substances (Kruskal-Wallis test, $\mathrm{P}<$ 0.05 ). Since apoptotic cells show red fluorescence in the images, the effect on MCF-7 is seen more clearly (Fig. 2). This situation is compatible with today's cancer treatment methods. Because today, when some drugs are treated in combination to the cancer patients, the treatment process is shorter and the positive results are obtained sooner than the individual drugs are treated (Sayek, 1996). In the study of Pegram et al. (2004), it has been shown that trastuzumab and carboplatin, 4-hydroxycyclophosphamide, docetaxol, or vinorelbine show consistent synergistic interactions at clinically significant concentrations in HER-2 overexpressing breast cancer cells and these combinations can be tested in human clinical trials.

When the cytotoxic effect of the substances on the SVCT cell line was examined by microscopic images, it was found that bassiatin has the least toxic effect on SVCT (Fig. 2). It was observed that bassiatin did not show toxic effects in almost all concentrations compared to the control group. Even at low concentrations, tamoxifen was found to be more toxic on SVCT cell line than bassiatin and the combined substance. Red fluorescence in SVCT cells also show the apoptotic effect of tamoxifen (Fig. 2). In normal breast epithelial cells, the toxic effect of tamoxifen which is used in the treatment of breast cancer cannot be considered as a target-oriented substance in treatment and even if it is used in breast cancer treatment, it may cause many disorders in patients. This study indicates that bassiatin may be considered as a potential new breast cancer agent because of its high toxicity on MCF-7 and its minimal toxic effect on normal breast epithelium. In a study conducted by Meng et al. (2011), bassiatin was found to be effective on the MCF7 cell line, but these scientists did not experiment with tamoxifen comparatively. In our study, we found for the first time that bassiatin is a more appropriate agent than tamoxifen. The appropriateness of the combined use of both substances was also presented for the first time with this study.

When the concentrations of the substances on the MCF-7, MDA-MB-231, SK-BR-3 and SVCT cell lines were compared with the bar graphs at $24 \mathrm{~h}$ incubation period, it has been shown that all substances are active and may inhibit cell proliferation at certain doses compared to control on the MCF-7 cell line (Fig. 3). It was statistically determined that the most effective substance in almost all doses is the combined substance on the MCF-7 cell line (Mann-Whitney $\mathrm{U}$ test, $\mathrm{P}<0.05$ ). When the effect of bassiatin on cell lines is evaluated, it is seen that the most toxic effect is shown on MCF-7 in all incubation periods. However, each cell line appears to inhibit proliferation in other breast cancer cell lines when compared to the control group. When the effects of tamoxifen on different cell lines were compared, it was found to be most toxic in SVCT cell line compared to cancer cell lines (Mann-Whitney U test, $\mathrm{P}<0.05)$. In addition, both the MDA-MB-231 and SK-BR-3 cell lines showed a toxic effect on the MCF-7 cell line. This suggests that tamoxifen, which is used as an inhibitor of oestrogen receptor activity in hormone therapy, may affect different foci except ER. Scandlyn et al. (2008) also showed a new role of tamoxifen in ER-negative MDA-MB-231 cell line when it is combined with epigallocatechin gallate. Both the bassiatin and the combined substance in the SK-BR-3 breast cancer cell line, which do not carry the oestrogen receptor, were found to have a toxic effect. This suggests that we can evaluate bassiatin as an agent that targets different foci except the oestrogen receptor. In the triple-negative MDAMB-231 cell line, a low toxic effect compared to other cell lines suggests that bassiatin has a receptor blocking feature. In the SVCT cell line, it was found that bassiatin has no toxic effect other than the slight inhibition that it showed in the $24 \mathrm{~h}$ incubation while tamoxifen exhibited severe toxic effect especially after $48 \mathrm{~h}$ of incubation (Fig. 3). When the statistical results are evaluated; there was no significant difference between the toxic effects of the substances in the low doses $(\mathrm{P}>0.05)$, although there was a significant difference in the high doses between the substances during three incubation periods on the MCF-7 cell line $(\mathrm{P}<0.05)$. On SVCT, the difference between the substances was found to be significant, except for some low doses in the $24 \mathrm{~h}$ incubation $(\mathrm{P}<0.05)$. It can be seen from Fig. 2 that this condition is caused by the high toxicity of tamoxifen on normal breast epithelium cells.

Comparisons of MVF-7 and SVCT cell lines in terms of concentrations of the substances are shown in graphs. The toxic effect of bassiatin on MCF-7 appears to be greater in all three incubation periods compared with the SVCT cell line. The toxic effect of tamoxifen increased in both cell lines when the dose of tamoxifen increased. However, it has been found that tamoxifen has more toxicity on SCVT cell line compared with MCF-7. Although the combined substance was found to be toxic in both cell lines, its activity was found to be much higher in the MCF-7 cell line than in SVCT (Fig. 4).

The cell cycle consists of the resting phase G0, G1, S, G2 and the mitotic M phases. There are checkpoints in the cell cycle. The situation of cell size and DNA damage are assessed at the G1/S; genotoxic stress is assessed at the G2/M and some other mistakes before division are assessed at $\mathrm{M}$ checkpoints. If any damage is detected at these checkpoints, the cell cycle stops. However, if there is no any abnormality in the cell cycle, the cell continues to divide. In cancer cells, these checkpoints are disabled and therefore continuous division is observed. The substances to be used in cancer treatment are expected to activate these checkpoints and prevent cell proliferation. In the evaluation of cell cycle analyses, the data obtained using flow cytometry device are shown with histograms. When the 24-h tamoxifen, bassiatin and combined substance incubations in MCF-7 cells compared with the control, it was shown that there is a reduction in the G0/G1 phase because of these substances especially bassiatin while these substances except combined substance increased S phase of MCF-7 cell cycle. It is also seen that all substances cause a reduction in the G2/M phase as shown in the G0/ G1 phase (Fig. 5). Compared to the 48-h incubation period with the control, tamoxifen was found to have reduction effect in the G0/G1 phase while all the substances contributed to the reduction in the $S$ phase. In contrast, tamoxifen, bassiatin and combined substance 
increased G2/M phase and provided in cell cycle progression in 48 $\mathrm{h}$ incubation period of MCF-7. When the 24 and $48 \mathrm{~h}$ tamoxifen, bassiatin and combined substance incubations in SVCT cells compared with the control, tamoxifen induces the reduction in G0/G1 phase while tamoxifen and bassiatin promote cells separately to $\mathrm{S}$ phase and cause $S$ phase increase. It was also found that the combined substance leads to increase in the G2/M phase (Fig. 5).

It has been found that tamoxifen, bassiatin and combined substance incubation for both 24 and $48 \mathrm{~h}$ in MCF-7 and SVCT cells have little effect on the cell cycle characteristics of the cells. The finding that bassiatin causes reduction at $24 \mathrm{~h}$ incubation and tamoxifen causes reduction at $48 \mathrm{~h}$ incubation in the G0/G1 phase of the MCF-7 cell line is consistent with the results obtained in cytotoxicity studies. Despite that; tamoxifen, bassiatin, and combined incubation have been shown to induce an increase at $S$ phase in both cell lines, thus proliferating cells are active in cell cycle progression. Meng et al. (2011) found that bassiatin induces MCF-7 cell cycle arrest at the G0/G1 phase in the presence of oestrogen in time-dependent incubation. However, this effect is reported to be very low in the absence of oestrogen. The results obtained using bassiatin in our cell cycle analysis without oestrogen are consistent with this study. Furthermore, the effect of bassiatin on the MCF-7 cell cycle suggests that bassiatin may be considered as a possible breast cancer agent, as it currently has similar results with tamoxifen, which is actively used in breast cancer therapy.

Quantitative measurements of ER, EGFR and VEGFR with the effect of bassiatin, tamoxifen and combined substance used in the study on MCF-7 and SVCT cell lines were performed with commercial ELISA kits and the obtained results were evaluated with bar graphs. When the results obtained from oestrogen receptor detection studies are evaluated, all three substances were found to interact with the oestrogen receptor and contribute to cell inhibition according to the control group in the MCF-7 cell line (Table 2). The amount of unbound oestrogen receptor was rarely found especially in combined substance-treated cells indicates that this treatment contributes to receptor-dependent inhibition (Fig. 6). In breast cancer development, the activity of hormones such as oestrogen in breast cancer was discovered by the detection and effects of the oestrogen receptor on cell lines like MCF-7 (Brooks et al., 1973, Martin \& Weber, 2000). It was thought that oestrogen receptor blocking agents would be a solution in the treatment of breast cancer. The action mechanism of tamoxifen was known with studies to act by binding to the oestrogen receptor, preventing oestrogen from inducing the cells and inhibiting cell proliferation (Zhang et al., 1999, Stewart \& Wild, 2014). Bassiatin was also found to act by binding to the oestrogen receptor in the MCF-7 cell line (Meng et al., 2011). However, the comparison of two substances and the high effect of the combination of these substances have shown for the first time with this study. In the SVCT cell line study, it was observed that all substance incubations gave similar results to the control, whereas tamoxifen was shown to be the least likely to bind the oestrogen receptor as the result of the incubation (Fig. 6).

The studies for EGFR detection gave similar results with ER $\alpha$ studies (Table 2). This demonstrates that the combined substance may inhibit the proliferation and growth of the cancerous cell by inhibiting receptors induced by the epithelial growth factor as well as the oestrogen receptor (Fig. 6). It is known that the epithelial growth factor induces the growth and proliferation of cancerous cells and the rapid progression of cancer like oestrogen (Fan et al., 2007, Karaca Güzel, 2005). The demonstration of the inhibition effect of bassiatin at both receptors strengthens bassiatin to be considered as a possible breast cancer agent.

In VEGFR detection studies, the amount of receptors in all com- parisons, including control, was low. This can be explained by the presence of this receptor in both cell lines, normally in small amounts (Table 2). Nevertheless, comparative results have shown similar results to other receptor studies, suggesting that the combined substance causes inhibition of the receptors induced by the vascular endothelial growth factor (Fig. 6). This suggests that it contributes to the inhibition of an important step such as vascularization in tumour formation. Garvin et al. (2005) were found that tamoxifen reduces at high levels the amount of unbound VEGFR with oestrogen in MCF-7 tumours with in vivo studies. In addition, it is compatible with our results that only tamoxifen treatment, even in small amounts, reduces the amount of VEGFR. As a matter of fact, there is an interpretation that cell inhibition in the presence of oestrogen may be more in the analysis of the cell cycle. The presence of oestrogen released at different levels according to hormonal balance and transmitted to specific sites of the body in women suggests that the detected effects of bassiatin, tamoxifen and combined substance may be greater in vivo compared with in vitro.

In conclusion, this study demonstrates that bassiatin which is obtained with our study is more effective than tamoxifen on the MCF-7 breast cancer cell line, this effect is achieved by receptor inhibition and the combined use of tamoxifen and bassiatin may be suitable for breast cancer treatment. This situation shows that bassiatin is as stable as tamoxifen in cell culture studies and it can be used in the long-term cancer treatment. Examining the efficacy of the substances on normal breast epithelial cells in this study was important for us to understand what kind of damage could be caused by a substance to be treated on patients in the future. The low efficacy of bassiatin on SVCT normal breast epithelial cell line compared with tamoxifen suggests that bassiatin can be regarded as a breast cancer treatment agent. The finding that high toxic effect of bassiatin on MCF-7 breast cancer cell line is based on receptor inhibition suggests that it can be used during hormonotherapy, such as SERM tamoxifen. Unlike the case of Meng et al. (2011), it has been found that, since bassiatin provides EGFR and VEGFR inhibition besides ER inhibition, it cannot be regarded as only an antiestrogenic substance. Although the efficacy of bassiatin in breast cancer cell lines is expected to be characteristic of a cancer agent, it should be remembered that this study is carried out in vitro. It is necessary to look at the pharmaceutical effect by making clinical experiments and studies necessary for the next step of the study and for the commercial use of bassiatin in cancer treatment. Thus, positive results from this study and the results of pharmaceutical and in vivo drug efficacy studies will be evaluated to demonstrate the suitability of bassiatin for cancer treatment.

\section{Acknowledgements}

I would like to thank Assoc. Prof. Dr. Özer Aylin Gürpınar, Dr. Handan Sevim and Dr. Hande Canpınar for her contribution during the planning and development of whole analysis.

Funding: This study was funded by The Scientific and Technological Research Council of Turkey, TUBİTAK (Grant number: 215S096)

Conflict of Interest: The authors declare that they have no conflict of interest.

Ethical Approval: This article does not contain any studies with human participants or animals by any of the authors.

\section{References}

Al-Hajj, M., Wicha, M. S., Benito-Hernandez, A., Morrison, S. J., \& Clarke, M. F. (2003).

Prospective identification of tumorigenic breast cancer cells. Proceedings of the $\mathrm{Na}$ - 
tional Academy of Sciences, 100, 3983-3988. https://doi.org/10.1073/pnas.0530291100

Andre, F., Slimane, K., Bachelot, T., Dunant, A., Namer, M., Barrelier, A., ... Spielmann, M. (2004). Breast cancer with synchronous metastases: trends in survival during a 14-year period. Journal of Clinical Oncology, 22, 3302-3308. https:// doi.org/10.1200/JCO.2004.08.095

Brooks, S. C., Locke, E. R., \& Soule, H. D. (1973). Estrogen receptor in a human cell line (MCF-7) from breast carcinoma. The Journal of Biological Chemistry, 248, 6251-6253.

Deeb, D., Gao, X., Dulchavsky, S. A., \& Gautam, S. X. (2007). CDDO-me induces apoptosis and inhibits Akt, mTOR and NF-kappaB signaling proteins in prostate cancer cells. Anticancer Research, 27, 3035-3044.

Fan, P., Wang, J., Santen, R. J., \& Yue, W. (2007). Long-term Treatment with Tamoxifen Facilitates Translocation of Estrogen Receptor A out of the Nucleus and Enhances its Interaction with EGFR in MCF-7 Breast Cancer Cells. Cancer Research, 67, 1352-1360. https://doi.org/10.1158/0008-5472.CAN-06-1020

Garvin, S., Nilsson, U. W., \& Dabrosin, C. (2005). Effects of oestradiol and tamoxifen on VEGF, soluble VEGFR-1, and VEGFR-2 in breast cancer and endothelial cells. British Journal of Cancer, 93, 1005-1010. https://doi.org/10.1038/sj. bjc. 6602824

Guo, P., Fang, Q., Tao, H. Q., Schafer, C. A., Fenton, B. M., Ding, I., Hu, B., \& Cheng, S. Y. (2003). Overexpression of Vascular Endothelial Growth Factor by MCF-7 Breast Cancer Cells Promotes Estrogen-independent Tumor Growth in Vivo. Cancer Research, 63, 4694-4691.

Huang, B., Guo, J., Yi, B., Yu, X., Sun, L., \& Chen, W. (2008). Heterologous production of secondary metabolites as pharmaceuticals in Saccharomyces cerevisiae. Biotechnology Letters, 30, 1121-1137. https://doi.org/10.1007/s10529-0089663-z

Ikeda, K., \& Inoue, S. (2004). Estrogen receptors and their downstream targets in cancer. Archives of Histology and Cytology, 67, 435-442. https://doi.org/10.1679/ aohc. 67.435

Jemal, A., Bray, F., Center, M. M., Ferlay, J., Ward, E., \& Forman, D. (2011). Global cancer statistics. CA: A Cancer Journal of Clinicians, 61, 69-90. https://doi. org/10.3322/caac.20107

Kagamizono, T., Nishino, E., Matsumoto, K., Kawashima, A., Kishimoto, M., Sakai, N., He, B. M., Chen, Z. X., Adachi, T., Morimoto, S., \& Hanada, K. (1995). Bassiatin, a new platelet aggregation inhibitor produced by Beauveria bassiana K-717. The Journal of Antibiotics, 48, 1407-1412. https://doi.org/10.7164/antibiotics.48.1407

Karaca Güzel, G. P. (2005). Examination of ErbB receptor distribution and cell proliferation in breast cancer cells by immunocytochemical method (in Turkish). Master's thesis, Istanbul, Turkey: Kadir Has University.

Keller, N. P., Turner, G., \& Bennett, J. W. (2005). Fungal secondary metabolism - from biochemistry to genomics. Nature Reviews Microbiology, 3, 937-947. https://doi. org/10.1038/nrmicro1286

Keskin, N., Ozgor, E., Celebier, I., \& Ulusoy, M. (2016). The Effect of Bassiatin As a Novel Antiseptic Agent on Methicillin-Resistant Staphylococcus aureus. Journal of Biotechnology, 231, S76. https://doi.org/10.1016/j.jbiotec.2016.05.276

Martin, A. M., \& Weber, B. L. (2000). Genetic and hormonal risk factors in breast cancer. Journal of the National Cancer Institute, 92, 1126-1135. https://doi. org/10.1093/jnci/92.14.1126

Meng, L., Feng, B., Tao, H., Yang, T., Meng, Y., Zhu, W., \& Huang, C. (2011). A novel antioestrogen agent (3R,6R)-bassiatin inhibits cell proliferation and cell cycle progression by repressing cyclinD1 expression in 17b-oestradiol-treated MCF-7 cells. Cell Biology International, 35, 599-605. https://doi.org/10.1042/CBI20100765

Meng, L., Tao, H., Dong, G., Yang, T., Zhang, W., Zhu, W., \& Huang, C. (2012). ERK1/2 and Akt pathway activated during (3R,6R)-bassiatin(1)-induced apoptosis in MCF-7 cells. Cell Biology International, 36, 345-348. https://doi. org/10.1042/CBI20110388

Muss, H. B., Case, L. D., Richards, F., White, D. R., Cooper, M. R., Cruz, J. M., Powell, B. L., Spurr, C. L., Capizzi, R. L. \& Piedmont Oncology Association. (1991). Interrupted versus continuous chemotherapy in patients with metastatic breast cancer. New England Journal of Medicine, 325, 1342-1348. https://doi.org/10.1056/ NEJM199111073251904

Olayioye, M. A. (2001). Intracellular signaling pathways of ErbB2/HER2 and family members. Breast Cancer Research, 3, 385-389. https://doi.org/10.1186/bcr327

Pegram, M. D., Konecny, G. E., O’Callaghan, C., Beryt, M., Pietraz, R., \& Slamon, D. J. (2004). Rational combinations of trastuzumab with chemotherapeutic drugs used in the treatment of breast cancer. Journal of the National Cancer Institute, 96 739-749. https://doi.org/10.1093/jnci/djh131

Pettit, R. K., Pettit, G. R., Xu, J. P., Weber, C. A., \& Richert, L. A. (2010). Isolation of Human Cancer Cell Growth Inhibitory, Antimicrobial Lateritin from a Mixed Fungal Culture. Planta Medica, 76, 500-501. https://doi.org/10.1055/s-0029-1240617

Ruff, M., Gangloff, M., Wurtz, J. M., \& Moras, D. (2000). Estrogen receptor transcription and transactivation: structure-function relationship in DNA- and li- gand-binding domains of estrogen receptors. Breast Cancer Research, 2, 353259. https://doi.org/10.1186/bcr80

Sayek, İ. (1996). Breast Diseases. In: İ. Sayek \& M. M. Özmen (Eds.), Basic Surgery (in Turkish) (pp. 864-872). Ankara: Güneş Publisher.

Scandlyn, M. J., Stuart, E. C., Somers-Edgar, T. J., Menzies, A. R., \& Rosengren, R. J. (2008). A new role for tamoxifen in oestrogen receptor-negative breast cancer when it is combined with epigallocatechin gallate. British Journal of Cancer, 99, 1056-1063. https://doi.org/10.1038/sj.bjc.6604634

Stewart, B. W., \& Wild, C. P. (2014) World cancer report 2014. In: B.W. Stewart \& C. P. Wild (Eds.), World Health Organization.

Walker, R. A., \& Dearing, S. J. (1999). Expression of epidermal growth factor receptor mRNA and protein in primary breast carcinomas. Breast Cancer Research and Treatment, 53, 167-176. https://doi.org/10.1023/A:1006194700667

Zhang, G. J., Kimijima, I., Onda, M., Kanno, M., Sato, H., Watanabe, T., Tsuchiya, A., Abe, R. \& Takenoshita, S. (1999). Tamoxifen-induced Apoptosis in Breast Cancer Cells Relates to Down-Regulation of bcl-2, but not bax and bcl-XL, without Alteration of p53 Protein Levels. Clinical Cancer Research, 5, 2971-2977. 